\title{
鼻腔癌54例の臨床的検討
}

久留米大学医学部耳鼻咽喉科・頭頸部外科学講座

坂 本 菊男, 高根 陽子,

宮嶋 義 巳, 中島 格

\section{Clinical Evaluation of Treatments of 54 Patients with Carcinoma of the Nasal Cavity}

\author{
Kikuo Sakamoto, Youko Takane, Yoshimi Miyajima, \\ Tadashi Nakashima
}

Department of Otolaryngology-Head and Neck Surgery, Kurume University School of Medicine

We analyzed the clinical features of 54 patients (33 males, 21 females, mean age 62 years) with carcinoma of the nasal cavity who underwent radical treatment at Kurume University Hospital between 1980 and 2003.

The $\mathrm{T}$ classification was $\mathrm{T} 1$ in 15 cases, $\mathrm{T} 2$ in 10 cases, $\mathrm{T} 3$ in 20 cases, and $\mathrm{T} 4$ in 9 cases. The $\mathrm{N}$ classification was N0 in 52 cases and N2 in 2 cases. There were 15 stage I cases, 10 stage II cases, 19 stage III cases, and 10 stage IV cases. There were six histopathological types of tumor, and squamous cell carcinoma was the most common.

Surgery was performed in all 54 cases. In 18 patients, the primary disease was treated by surgery alone. In 27 cases treatment was by surgery and supportive radiotherapy. One case was treated by surgery and supportive chemotherapy. Eight cases were treated by a combination of surgery, radiotherapy, and chemotherapy.

The disease-specific 5-year and 10-year survival rate was $74 \%$ (T1:77\%, T2:90\%, T3:77\%, T4: 40\%; Stage I : $77 \%$, Stage II : $89 \%$, Stage III : $83 \%$, Stage IV : 43\%). The 5-year local control rate was $76 \%$. The disease-specific 5-year survival rate according to histopathological type was squamous cell carcinoma $65 \%$, adenoid cystic carcinoma 83\%, adenocarcinoma 100\%. Local recurrence was detected in 16 cases (mean interval : 28 months). According to histopathological type, recurrence was detected in 8 cases of squamous cell carcinoma, 5 cases of adenoid cystic carcinoma, 2 cases of undifferentiated carcinoma, and 1 case of adenocarcinoma. Thirteen patients died of their primary disease ( 7 deaths from locoregional disease, 5 from distant metastasis, and 1 from complications).

The results of this retrospective review indicate the need for postoperative adjuvant radiotherapy for carcinoma of the nasal cavity and emphasize the need for both radiotherapy and chemotherapy after surgery for histopathologically high-grade malignancies.

Key words : carcinoma of the nasal cavity, treatment outcome, histopathology 


\section{はじめに}

鼻腔に発生する悪性腫瘍は多彩な病理組織型を示す。 鼻腔悪性腫瘍の UICC による TNM分類は第 6 版（2002 年改定）で定められた1)。鼻腔悪性腫瘍の治療方針は病 理組織型や腫瘍の浸潤範囲によって手術，放射線治療， 化学療法を単独，或いは組み合わせて行っているが確立 した治療法はない。そこで当科で治療した症例について 振返り，今後の治療法をより適切にするために臨床像と 治療法, 治療成績について検討したので報告する。

\section{対象と方法}

1980年から 2003 年までに久留米大学耳鼻咽喉科で根治 治療を行った鼻腔悪性腫瘍54例（男性33例，女性21例） を対象とした。年齢は20歳から87歳, 平均62歳である。 生存例の平均観察期間は 7 年10ヶ月である。 TN 分類を 表 1 に示す。

これらの症例について, 以下の項目について検討を行 った。(1)病理組織型，(2)腪瘍の浸潤範囲，(3)治療方法,

(4)手術法，(5)原発巣再発例，(6)頸部リンパ節再発例，(7) $\mathrm{T}$ 分類, 病理組織型, 治療法, 病期別の死因特異的 5 年 累積生存率と死因, (8)浸潤範囲の評価と 3 年, 5 年局所 制御率, (9)病理組織型別の 3 年, 5 年局所制御率, (10)治 療法別の 3 年, 5 年局所制御率, (11)扁平上皮癌の治療法 別の 3 年, 5 年生存率と死因。

腫瘍の浸潤範囲は内側 (鼻中隔, 対側鼻腔), 外側 （上鼻甲介，中鼻甲介，下鼻甲介，上顎洞，穊骨洞，眼 窩内), 後方 (翼状突起, 蝶形骨洞, 上咽頭), 前方 (鼻 前庭), 上方（篩板, 頭蓋内), 下方（鼻腔底, 硬口蓋） への浸潤の有無を調べた。浸潤範囲の評価は肉眼所見, X線， CT，MRI，手術所見などより総合的に行った。 治療方法は手術単独, 手術 + 放射線, 手術 + 化学療法, 手術 + 放射線 +化学療法に分類した。化学療法はシスプ ラチン, 5-FU, ペプロマイシン, エトポシドなどを組 み合わせて行った。他病死を打ち切りとした生存率と局 所制御率の算出には Kaplan-Meier 法を用いた。ま た， 2 群間の比較には Logrank-test を用いた。

\section{結果}

\section{（1）病理組織型}

病理組織型は, 扁平上皮癌が32例と最も多く, 腺様豪 胞癌： 12 例, 腺癌 : 4 例, 未分化癌 : 3 例, 粘表皮癌： 2 例，小細胞癌： 1 例であった。

(2) 腫瘍の浸潤範囲

腫瘍の浸潤範囲を表 2 に示す。鼻腔の外側方向に浸潤
表 1 対象症例，TN 分類（UICC2002）

\begin{tabular}{|c|r|c|c|}
\hline TN & N0 & N2 & 計 \\
\hline \hline T1 & 15 & 0 & 15 \\
\hline T2 & 9 & 1 & 10 \\
\hline T3 & 19 & 1 & 20 \\
\hline T4 & 9 & 0 & 9 \\
\hline \hline 計 & 52 & 2 & 54 \\
\hline
\end{tabular}

表 2 腫場の浸潤範囲

\begin{tabular}{|c|c|c|c|}
\hline & & 浸潤あり & 浸潤なし \\
\hline 内側 & $\begin{array}{l}\text { 鼻中隔 } \\
\text { 対側鼻腔 }\end{array}$ & $\begin{array}{ll}25 & (46 \%) \\
10 & (19 \%)\end{array}$ & $\begin{array}{ll}29 & (54 \%) \\
44 & (81 \%)\end{array}$ \\
\hline 外側 & $\begin{array}{l}\text { 上鼻甲介 } \\
\text { 中䕗甲介 } \\
\text { 下鼻甲介 } \\
\text { 上顎洞 } \\
\text { 穊骨洞 } \\
\text { 眼窩内 }\end{array}$ & $\begin{aligned} 17 & (31 \%) \\
32 & (59 \%) \\
43 & (80 \%) \\
24 & (44 \%) \\
17 & (31 \%) \\
5 & (9 \%)\end{aligned}$ & $\begin{array}{ll}37 & (69 \%) \\
22 & (41 \%) \\
11 & (20 \%) \\
30 & (56 \%) \\
37 & (69 \%) \\
49 & (91 \%)\end{array}$ \\
\hline 後方 & $\begin{array}{l}\text { 翼状突起 } \\
\text { 蝶形骨洞 } \\
\text { 上咽頭 }\end{array}$ & $\begin{array}{ll}1 & (2 \%) \\
6 & (11 \%) \\
5 & (9 \%)\end{array}$ & $\begin{array}{ll}53 & (98 \%) \\
48 & (89 \%) \\
49 & (91 \%)\end{array}$ \\
\hline 前方 & 鼻前庭 & $4(7 \%)$ & $50(93 \%)$ \\
\hline 上方 & $\begin{array}{l}\text { 篩板 } \\
\text { 頭蓋内 }\end{array}$ & $\begin{array}{c}8(15 \%) \\
0\end{array}$ & $\begin{array}{l}46 \quad(85 \%) \\
54 \quad(100 \%)\end{array}$ \\
\hline 下方 & $\begin{array}{l}\text { 鼻腔底 } \\
\text { 硬口蓋 }\end{array}$ & $\begin{aligned} 15 & (28 \%) \\
7 & (13 \%)\end{aligned}$ & $\begin{array}{ll}39 & (72 \%) \\
47 & (87 \%)\end{array}$ \\
\hline
\end{tabular}

を示す症例が多く，下鼻甲介に浸潤していた症例は $80 \%$ におよんだ。上下方向では下方に浸潤する例が多かっ た。

（3）治療方法

全例に手術を施行していた。治療は手術のみ：18例， 手術+放射線：27例, 手術+放射線+化学療法：8例, 手術+化学療法：1例であった。

(4)：手術法

手術法は上顎部分切除術 : 41例, 鼻腔腫瘍摘出術 : 8 例, 頭蓋底手術： 3 例, 上顎洞試験開洞術： 1 例, 両側 上顎部分切除術：1例であった。眼営内容摘出術を併用 した症例は頭蓋底手術を施行しだ例の 1 例のみであっ た。上顎洞試験開洞術は腫瘍の減量を行った。

(5) 原発巣再発例

局所再発を 16 例に認めた。再発までの期間は 1 ケ月〜 7 年 5 ケ月（平均 2 年 4 ケ月）であった。再発例の病理 組織型は扁平上皮癌: 8 例, 腺様囊胞癌 : 5 例, 未分化 癌： 2 例, 腺癌：1例であった。 5 年以上して再発した 
表 $3 \mathrm{TN}$ 分類別の生存率と死因

\begin{tabular}{|c|c|c|c|c|c|c|c|c|}
\hline \multirow{2}{*}{$\mathrm{TN}$ 分類 } & \multirow{2}{*}{ 症例数 } & \multicolumn{2}{|c|}{ 死因特異的生存率 } & \multicolumn{4}{|c|}{ 死 } & 死亡例 \\
\cline { 3 - 8 } & & 5 年 & 10 年 & 原発単死 & 合併症死 & 遠隔転移死 & 他病死 & 合 \\
\hline \hline T1 & 15 & $77 \%$ & $77 \%$ & 2 & 0 & 1 & 3 & 6 \\
$\mathrm{~T} 2$ & 10 & $90 \%$ & $90 \%$ & 0 & 0 & 1 & 0 & 1 \\
$\mathrm{~T} 3$ & 20 & $77 \%$ & $77 \%$ & 4 & 1 & 0 & 1 & 6 \\
$\mathrm{~T} 4$ & 9 & $40 \%$ & $40 \%$ & 1 & 0 & 3 & 2 & 6 \\
\hline $\mathrm{N} 0$ & 52 & $75 \%$ & $75 \%$ & 6 & 1 & 5 & 6 & 18 \\
$\mathrm{~N} 2$ & 2 & - & - & 1 & 0 & 0 & 0 & 1 \\
\hline \hline 合計 & 54 & $74 \%$ & $74 \%$ & 7 & 1 & 5 & 6 & 19 \\
\hline
\end{tabular}

一：経過例なし

表 4 病理組織別の生存率と死因

\begin{tabular}{|c|c|c|c|c|c|c|c|c|}
\hline \multirow{2}{*}{ 病理組織型 } & \multirow{2}{*}{ 症例数 } & \multicolumn{2}{|c|}{ 死因特異的生存率 } & \multicolumn{4}{|c|}{ 死 } & \multirow{2}{*}{$\begin{array}{c}\text { 死亡例 } \\
\text { 合計 }\end{array}$} \\
\hline & & 5 年 & 10年 & 原発巣死 & 合併症死 & 遠隔転移死 & 他病死 & \\
\hline 扁平上皮癌 & 32 & $65 \%$ & $65 \%$ & 6 & 0 & 4 & 4 & 14 \\
\hline 腺様囊胞癌 & 12 & $83 \%$ & $83 \%$ & 1 & 1 & 0 & 0 & 2 \\
\hline 腺癌 & 4 & $100 \%$ & $100 \%$ & 0 & 0 & 0 & 0 & 0 \\
\hline 未分化癌 & 3 & $100 \%$ & $100 \%$ & 0 & 0 & 0 & 1 & 1 \\
\hline 粘表皮癌 & 2 & $50 \%$ & - & 0 & 0 & 1 & 0 & 1 \\
\hline 小細胞癌 & 1 & $100 \%$ & - & 0 & 0 & 0 & 1 & 1 \\
\hline 合計 & 54 & $74 \%$ & $74 \%$ & 7 & 1 & 5 & 6 & 19 \\
\hline
\end{tabular}

一：経過例なし

例は腺様囊胞癌： 2 例，扁平上皮癌：1例であった。16 例のうち追加治療により生存しているのは 7 例であり, 担癌生存中が 1 例, 原発巣死は 7 例, 追加治療により原 発巣は制御できたが心疾患で死亡した例が 1 例であっ た。

\section{(6) 頸部リンパ節再発例}

頸部リンパ節再発は N0：52例のうち 2 例（3.8\%）に 認めた。 1 例は扁平上皮癌 T4aN0 で治療開始から 3 ケ 月後に両側上内深頸リンパ節に転移が出現し頸部郭清術 により頸部は制御できたが 1 年 8 ケ月後に肺転移により 遠隔転移死した。もう 1 例は未分化癌 T1N0 で 2 年 9 ケ 月後に患側上内深頸リンパ節に転移が出現し, 頸部郭清 術により頸部も制御し 5 年経過している。

(7) T分類, 病理組織型, 治療法, 病期別の死因特異的 5 年累積生存率と死因

全症例の Kaplan-Meier 法による死因特異的累積 5 年，10年生存率は $74 \%$ であった。

$\mathrm{TN}$ 別の生存率と死因について表 3 に示す。T別の 5 年生存率は $\mathrm{T} 1: 77 \%, \mathrm{~T} 2: 90 \%, \mathrm{~T} 3: 77 \%, \mathrm{~T} 4: 40 \%$ であった。N0の 5 年生存率は $75 \%$ あった。N2の 5 年生存率は 1 例が 4 年生存しているが， 1 例は 2 年 4 ケ
月で原発巣死し算出不能であった。死亡例は19例で原発 巣死 7 例，遠隔転移死 5 例（肺： 3 例，肺之骨： 1 例, 脳：1例), 合併症死 1 例, 他病死 6 例であった。 $\mathrm{T} 1$ で も原発巣死 2 例, 遠隔転移死 1 例と原病死を 3 例認め た。

病理組織型別の生存率と死因について表 4 に示す。病 理組織型別の 5 年生存率は，扁平上皮癌が $65 \%$, 粘表皮 癌が $50 \%$ と不良であった。死因は扁平上皮癌による原病 死が10例と最多であった。

治療法別の生存率について表 5 に示す。 5 年生存率 は，手術のみ：77\%，手術＋放射線：74\%，手術＋放射 線＋化学療法：50\%, 手術十化学療法：100\%であった。

（8）浸潤範囲の評価と 3 年， 5 年局所制御率（表 6 ）

各部位別の浸潤範囲の有無別による局所制御率は鼻中 隔，穊板，頭蓋内では腫瘍浸潤がない方が局所制御率は 良好であった。

（9）病理組織型別の 3 年， 5 年局所制御率

全体の 3 年， 5 年局所制御率は $78 \% ， 76 \%$ あった。 病理組織型別の 5 年局所制御率は, 扁平上皮癌: $78 \%$, 腺様囊胞癌 : $75 \%$, 腺癌 : $75 \%$, 未分化癌 : $33 \%$, 粘表 皮癌：100\%，小細胞癌：100\%であった。 
表 5 治療法別の生存率

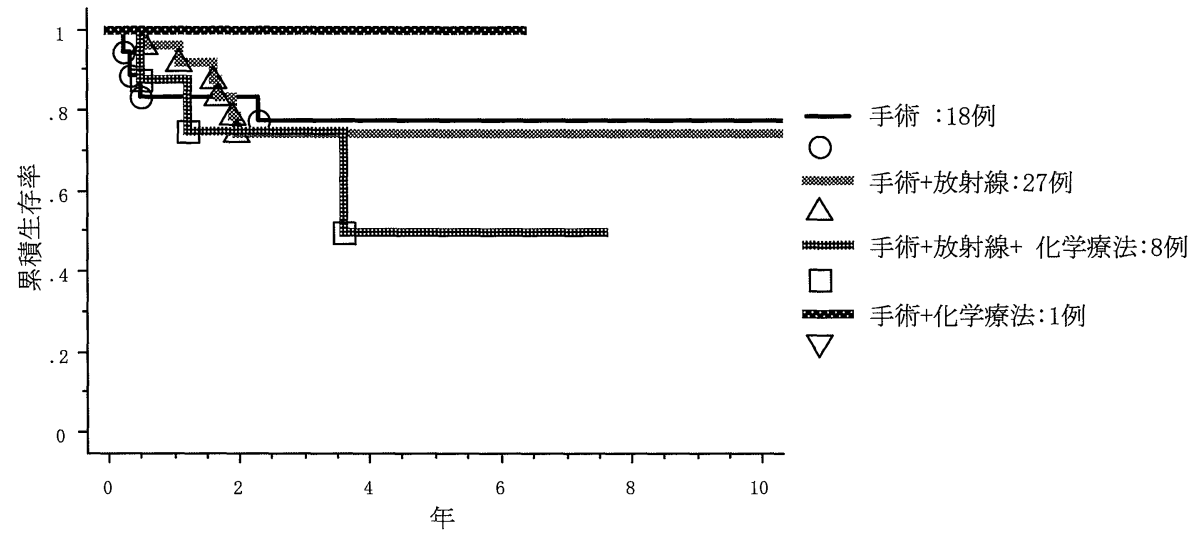

表 6 浸潤範囲の評価と局所制御率

\begin{tabular}{|c|c|c|c|c|c|c|c|}
\hline & 症例数 & 3 年局所制御率 & 5 年局所制御率 & & 症例数 & 3 年局所制御率 & 5 年局所制御率 \\
\hline $\begin{array}{l}\text { 鼻中隔 } \\
\text { 浸潤あり } \\
\text { 浸潤なし }\end{array}$ & $\begin{array}{l}25 \\
29\end{array}$ & $\begin{array}{l}72 \% \\
79 \%\end{array}$ & $\begin{array}{l}72 \% \\
79 \%\end{array}$ & $\begin{array}{l}\text { 翼状突起 } \\
\text { 浸潤あり } \\
\text { 浸潤なし }\end{array}$ & $\begin{array}{r}1 \\
53\end{array}$ & $\begin{array}{r}100 \% \\
77 \%\end{array}$ & $\begin{array}{r}100 \% \\
75 \%\end{array}$ \\
\hline $\begin{array}{l}\text { 対側鼻腔 } \\
\text { 浸潤あり } \\
\text { 浸潤なし }\end{array}$ & $\begin{array}{l}10 \\
44\end{array}$ & $\begin{array}{l}80 \% \\
77 \%\end{array}$ & $\begin{array}{l}80 \% \\
75 \%\end{array}$ & $\begin{array}{l}\text { 蝶形骨洞 } \\
\text { 浸潤あり } \\
\text { 浸潤なし }\end{array}$ & $\begin{array}{r}6 \\
48\end{array}$ & $\begin{array}{r}100 \% \\
75 \%\end{array}$ & $\begin{array}{r}100 \% \\
73 \%\end{array}$ \\
\hline $\begin{array}{l}\text { 上甲介 } \\
\text { 浸潤あり } \\
\text { 浸潤なし }\end{array}$ & $\begin{array}{l}17 \\
37\end{array}$ & $\begin{array}{l}76 \% \\
78 \%\end{array}$ & $\begin{array}{l}76 \% \\
76 \%\end{array}$ & $\begin{array}{l}\text { 上咽頭 } \\
\text { 浸潤あり } \\
\text { 浸潤なし }\end{array}$ & $\begin{array}{r}5 \\
49\end{array}$ & $\begin{array}{l}80 \% \\
78 \%\end{array}$ & $\begin{array}{l}80 \% \\
76 \%\end{array}$ \\
\hline $\begin{array}{l}\text { 中甲介 } \\
\text { 浸潤あり } \\
\text { 浸潤なし }\end{array}$ & $\begin{array}{l}32 \\
22\end{array}$ & $\begin{array}{l}78 \% \\
77 \%\end{array}$ & $\begin{array}{l}75 \% \\
77 \%\end{array}$ & $\begin{array}{l}\text { 鼻前庭 } \\
\text { 浸潤あり } \\
\text { 浸潤なし }\end{array}$ & $\begin{array}{r}4 \\
50\end{array}$ & $\begin{array}{r}100 \% \\
76 \%\end{array}$ & $\begin{array}{r}100 \% \\
74 \%\end{array}$ \\
\hline $\begin{array}{l}\text { 下甲介 } \\
\text { 浸潤あり } \\
\text { 浸潤なし }\end{array}$ & $\begin{array}{l}43 \\
11\end{array}$ & $\begin{array}{l}79 \% \\
73 \%\end{array}$ & $\begin{array}{l}77 \% \\
73 \%\end{array}$ & $\begin{array}{l}\text { 篩板 } \\
\text { 浸潤あり } \\
\text { 浸潤なし }\end{array}$ & $\begin{array}{r}8 \\
46\end{array}$ & $\begin{array}{l}63 \% \\
80 \%\end{array}$ & $\begin{array}{l}63 \% \\
78 \%\end{array}$ \\
\hline $\begin{array}{l}\text { 上顎洞 } \\
\text { 浸潤あり } \\
\text { 浸潤なし }\end{array}$ & $\begin{array}{l}24 \\
30\end{array}$ & $\begin{array}{l}79 \% \\
77 \%\end{array}$ & $\begin{array}{l}79 \% \\
73 \%\end{array}$ & $\begin{array}{l}\text { 頭蓋内 } \\
\text { 浸潤あり } \\
\text { 浸潤なし }\end{array}$ & $\begin{array}{c}0 \\
54\end{array}$ & $\begin{array}{r}0 \% \\
78 \%\end{array}$ & $\begin{array}{r}0 \% \\
76 \%\end{array}$ \\
\hline $\begin{array}{l}\text { 篩骨洞 } \\
\text { 浸潤あり } \\
\text { 浸潤なし }\end{array}$ & $\begin{array}{l}17 \\
37\end{array}$ & $\begin{array}{l}82 \% \\
76 \%\end{array}$ & $\begin{array}{l}82 \% \\
73 \%\end{array}$ & $\begin{array}{l}\text { 鼻腔底 } \\
\text { 浸潤あり } \\
\text { 浸潤なし }\end{array}$ & $\begin{array}{l}15 \\
39\end{array}$ & $\begin{array}{l}87 \% \\
74 \%\end{array}$ & $\begin{array}{l}87 \% \\
72 \%\end{array}$ \\
\hline $\begin{array}{l}\text { 眼窩内 } \\
\text { 浸潤あり } \\
\text { 浸潤なし }\end{array}$ & $\begin{array}{r}5 \\
49\end{array}$ & $\begin{array}{l}80 \% \\
78 \%\end{array}$ & $\begin{array}{l}80 \% \\
76 \%\end{array}$ & $\begin{array}{l}\text { 硬口蓋 } \\
\text { 浸潤あり } \\
\text { 浸潤なし }\end{array}$ & $\begin{array}{r}7 \\
47\end{array}$ & $\begin{array}{l}86 \% \\
77 \%\end{array}$ & $\begin{array}{l}86 \% \\
74 \%\end{array}$ \\
\hline
\end{tabular}

（10）治療法別の 3 年， 5 年局所制御率

5 年局所制御率は手術単独：61\%であったのに対し, 手術 +放射線：85\%, 手術+化学療法：100\%, 手術 + 放射線＋化学療法：75\%と手術に追加治療を行った群で 局所制御率は良好であった。手術単独と手術＋放射線の

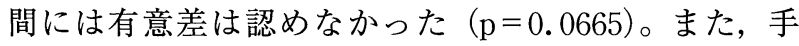
術単独と手術 + 放射線 + 化学療法の間にも有意差は認め なかった（p=0.4469）。

(11) 扁平上皮癌の治療法別の 3 年, 5 年生存率と死因 (表 7 )

5 年生存率は手術単独：71\%であったのに対し, 手術 +放射線：68\%，手術＋化学療法：100\%，手術＋放射 線＋化学療法：経過例なしであった。手術単独と手術 + 放射線の間には有意差は認めなかった（P=0.8662）。 
表 7 扁平上皮癌の治療法別の 3 年, 5 年生存率と死因

\begin{tabular}{|c|c|c|c|c|c|c|c|}
\hline \multirow{2}{*}{ 扁平上皮癌治療法 } & \multirow{2}{*}{ 症例数 } & \multicolumn{2}{|c|}{ 死因特異的生存率 } & \multicolumn{3}{|c|}{ 死 } & \multirow{2}{*}{$\begin{array}{c}\text { 死亡例 } \\
\text { 合計 }\end{array}$} \\
\hline & & 3 年 & 5 年 & 原発巣死 & 遠隔転移死 & 他病死 & \\
\hline 手術 & 7 & $71 \%$ & $71 \%$ & 2 & 0 & 0 & 2 \\
\hline 手術＋放射線 & 18 & $68 \%$ & $68 \%$ & 3 & 2 & 3 & 8 \\
\hline 手術＋化学療法 & 1 & $100 \%$ & $100 \%$ & 0 & 0 & 0 & 0 \\
\hline 手術＋放射線＋化学療法 & 6 & $67 \%$ & - & 1 & 2 & 1 & 4 \\
\hline 合計 & 32 & $70 \%$ & $65 \%$ & 6 & 4 & 4 & 14 \\
\hline
\end{tabular}

一：経過例なし

また，手術単独と手術＋放射線＋化学療法の間にも有意 差は認めなかった（P=0.3521）。

\section{考察}

鼻腔悪性腫瘍の臨床像について Frazell ら ${ }^{2)}$ が報告し て以来，多くの報告がみられる ${ }^{3-7)}$ 。病理組織型は多彩だ が最も多いのは扁平上皮癌である。今回の検討でも他の 報告 ${ }^{4,6)}$ と同じように扁平上皮癌が最多であった。鼻腔 の組織学的構造は鼻入口部から鼻根付近までは扁平上 皮，鼻根から下鼻甲介前端までは移行上皮，それ以降は 多列線毛円柱上皮からなりほとんど円柱上皮で占められ ているが，鼻腔に扁平上皮癌が多いのは扁平上皮化生が 関与していると考えられている8

腫瘍の浸潤範囲は外側方向が最も多く予後も不良であ るという報告が多い4)。今回の結果でも外側へ浸潤した 症例が多く，上下方向では下方に浸潤する症例が多かっ たが，前後方向へ浸潤する症例は少なかった。

我々の鼻腔癌に対する治療方法は病理組織型を確認後 に集学的治療を行っている。鼻腔癌はその解剖学的特徵 から十分な安全域を確保することが困難である。基本的 には外科的切除を行い，摘出標本の病理組織像を観察し 組織学的悪性度と切除安全域を検討した上で追加治療を 選択している。具体的には浸潤傾向の強い扁平上皮癌, 上皮性成分の多い粘表皮癌， solid pattern を多く占める 腺様囊胞癌などに追加治療を行っている。

5 年局所制御率は近藤ら ${ }^{9}$ が56\%であったと報告して いるが，今回の全体の 5 年局所制御率は $76 \%$ であり良好 であった。浸潤範囲別の局所制御率は鼻中隔，篩板に浸 潤のある方が不良であった。これはこの領域の安全域の 確保が十分でな⿰氵九たたためと思われた。Blacklock ら は，頭蓋底に浸潤した鼻副鼻腔癌 9 例に鼻側と経頭蓋の アプローチで手術を行い合併症もなく根治できたと報告 している。今回の検討では篩板への浸潤を 8 例に認めた が， 3 例が原発巣再発した。. 2 例は1980年代早期の症例 であり頭蓋底手術を開始する前の症例であった。1 例に
頭蓋底手術を施行したが原発巣死している。頭蓋底手術 を施行した他の 2 例は生存しており，篩板への浸潤が疑 われる症例では高浸襲ではあるが，積極的に頭蓋底手術 を行うべきである ${ }^{11,12)}$ 。Ian ら ${ }^{13)}$ は世界の17の施設で行 った1193例の頭蓋底手術例について検討し, 術後合併症 は $36.3 \%$ 症例にみられ，創傷治癒に関連するものが $19.8 \%$ と最も多く, 中枢神経症状は $16.2 \%$ に認めたが, 粗死亡率は $4.7 \%$ であり，頭蓋底手術は適応を注意深く 検討すれば安全な外科的治療であると報告している。当 科における頭蓋底手術の適応は海綿静脈洞に浸潤してお らず，健側の眼窩内浸潤が骨膜までの症例としてい る ${ }^{14)}$ 。当科の前頭蓋底手術を施行した24例についての検 討では術後合併症は $17 \%$ の症例にみられたのみで，高浸 襲ではあるが比較的安全な手術と考えている。一方，既 存の疾患により頭蓋底手術が行えない症例でも放射線治 療に超選択的動注化学療法を併用することで良好な原発 巣の制御を得ている例も経験している ${ }^{15)}$ 。根治手術が行 えない症例や手術を希望されない症例でも根治を期待で きる治療として選択肢が増えた。

再発までの期間は平均 2 年 4 ヶ月であり， 3 年間は厳 重な観察が必要である。 5 年以上して再発した例も 3 例 あり， 2 例が腺様囊胞癌であった。腺様囊胞癌の再発増 殖速度は遅いものの, perineural invasion をおこしやす く，術後に長期間を経て再発する例もあることから長期 の経過観察が必要である ${ }^{16)} 。$

$\mathrm{T}$ 分類別の死因特異的 5 年累積生存では $\mathrm{T} 1$ が $77 \%$ と 不良であったが, これは腺様囊胞癌の Grade III の症例 と扁平上皮癌の症例が原発巣死し, 粘表皮癌の高悪性型 の例が遠隔転移死したためである。今回の検討では T分 類別には比較的偏りはなかったが, Euteneuer ら゙) は, 初診時 T4 となっている進行例が多いことを述べてい る。鼻腔癌の 5 年生存率は McNicoll ら ${ }^{17)}$ は $52 \%, \mathrm{Hu}$ ら ${ }^{18)}$ は $62 \%$ と述べているが，われわれの結果は $74 \%$ と， これらの報告より良好であった。一方, 病理組織型別の 死因特異的 5 年累積生存率は粘表皮癌が50\%, 扁平上皮 
癌が $65 \%$ と不良であった。死因は扁平上皮癌による原病 死が10例と大部分を占めていた。扁平上皮癌の 5 年死因 特異的累積生存率はBoone ら $ら^{3)}$ は63\%, Frazel ら² は $56 \%$, Hawkins ら ${ }^{4)}$ は5 $5 \%$ と報告しており, 当科では 65\%でありほほ同等の成績であった。

Szanto ら ${ }^{19)}$ は腺様蘘胞癌の臨床像を解析するうえで 組織 Grade 分類を提唱している。我々は早期に再発し 不幸な経過をとる例が多い solid pattern を多く占める腺 様囊胞癌では術後の再発予防を目的に，1991年以降は Gradeによって術後放射線治療を行うようにしてい $3^{200}$ 。腺様囊胞癌の原発巣再発例は 1980 年代の症例であ り術後放射線治療を行っていなかった。腺様囊胞癌の悪 性度に応じた術後放射線治療の必要性を再認識した。

鼻腔腺癌の予後については扁平上皮癌より良好という 報告がある6)。腺癌は放射線治療や化学療法が奏功しに くいため外科的切除が主な治療となる ${ }^{21)}$ 。Orvidas ら ${ }^{21)}$ は，11例に頭蓋底手術を施行したが 4 例が原発巣死して おり, 頭蓋底に進展した例や高悪性度の例では拡大切除 を行っても術後放射線治療は生存率に影響なかったと報 告している。同じ腺系の組織像を示す耳下腺癌における 化学療法の経験からも化学療法は補助的なものであり根 治的な切除が必要である ${ }^{22)}$ 。Abecasis ら ${ }^{23)}$ は，14例の鼻 副鼻腔腺癌の神経内分泌マーカーを測定することにより 鼻副鼻腔原発なのか, 腸管からの転移によるものか鑑別 するのに価值があると述べているが，予後との関連は報 告していない。

未分化癌の 5 年生存率は $100 \%$ と良好であった。一方, Hawkins ら ${ }^{4)}$ は未分化癌の 5 年生存率 $46 \%$ であり, 扁平 上皮癌 $55 \%$ であったが両群間に有意な関係はなかったと の報告している。

粘表皮癌は管系上皮由来の腫瘍で粘液産生を示す細胞 と扁平上皮型の細胞とからなり, 臨床的に低悪性で比較 的予後の良いものと, 著しく悪性度の高いものとがあ り, 組織学的にも高分化型のものから低分化型のものま である ${ }^{24,25)}$ 。粘表皮癌の高悪性例は術後放射線治療を行 い原発巣は制御できたものの遠隔転移死しており悪性度 に応じて化学療法を検討すべきである。

小細胞癌は頭頸部領域では少なく ${ }^{26)}$, Kane $5^{27)}$ は耳 下腺小細胞癌の術後放射線治療の有效性を述べており, 化学療法については肺や喉頭の小細胞癌では有効として いる。Hakuba ら ${ }^{28)}$ は頭蓋底と眼窩に進展した鼻腔小細 胞癌にシスプラチンとイリノテカンを用いた化学療法を 施行し, 縮小した腫瘍を内視鏡下鼻内手術で可及的切除 を行い，ひき続いて術後放射線治療を施行し40ケ月局所 制御できた症例を報告している。当科での 1 例は，63歳
男性で術前照射を行い上顎部分切除術に続いて術後照射 とシスプラチンとエトポシドを用いた化学療法を施行 し, 7 年 7 ケ月後に急性心筋梗塞により他病死した例で ある。

$\mathrm{N}$ 分類別の死因特異的 5 年累積生存率では頸部リンパ 節転移例は予後不良との報告がみられる ${ }^{18)}$ 。今回の検討 ではわずかに 2 例のみであるが， 2 例とも頸部郭清術に より頸部は制御できていたが 1 例は原発巣死していた。 Hawkins ら ${ }^{4)}$ は，52例の N0 鼻腔癌のうち10例（19\%） に初期治療後にリンパ節転移を認めたとしているが，今 回の検討では 2 例 $(3.8 \%)$ と少なかった。

治療法別の局所制御率は, 手術単独に比べ追加治療を 行った群で局所制御率は良好であった。Hawkins ら は，手術十放射線と放射線単独の間には両群間に有意な 関係はなかったとの報告している。我々の施設では放射 線単独の治療例がなく比較できなかった。今回の検討で は手術単独と手術＋放射線の間には有意差は認めず，さ らに手術単独と手術 +放射線 + 化学療法の間にも有意差 は認めなかったが, 安全域の不足する例や病理組織学的 に悪性度の高い症例には放射線治療や化学療法などの追 加治療は他の頭頸部癌と同様に有用と考えており，他施 設からの報告を期待するとともに当科の長期成績で報告 したい。

鼻腔扁平上皮癌の治療法と予後について種々の治療法 を検討した報告はない。 $\mathrm{Hu}$ ら $^{18)}$ は扁平上皮癌の生存率 に抢いて放射線治療単独と手術+放射線治療の間に有意 な関係を認めたと報告している。今回の扁平上皮癌 32 例 の 5 年生存率の検討では手術単独例で $71 \%$ あっったのに 対し，手術十放射線は68\%で，この 2 群間に有意差は認 めなかった。手術単独例で生存率が手術十放射線例より 良好であった理由は早期の症例が半数を占め, 一方, 手 術＋放射線例では進行例が大半を占めたためである。今 後, 症例を増やし追加治療の有用性を検討したい。

\section{まとめ}

1. 1980年から 2003年に当科で治療を行った鼻腔癌 54 例の臨床的検討を行った。

2. 鼻腔癌の進展形式は外側方向が最も多く, 病理組 織型は扁平上皮癌が 32 例と最多であった。

3. 全体の死因特異的 5 年, 10 年生存率は $74 \%$ で, 5 年局所制御率は $76 \%$ であった。

4. 原病死は13例で, 原発巣死 7 例, 遠隔転移死 5 例, 合併症死 1 例であった。

5. 鼻腔癌は解剖学的特徵から十分な安全域を確保す ることが困難であり, 安全域の不足する例では術後放射 
線治療を行い, 病理組織学的に悪性度の高い症例には化 学療法も行うべきである。

本論文の要旨は第44回日本鼻科学会総会（2005年 9 月 30日，10月 1 日，大阪市）において口演した。

\section{文献}

1) International Union Against Cancer: TNM classification of malignant tumors. Sixth Edition Sobbin, L. H. and Wittekind Ch., New York: Wiley-Liss, 2002.

2) Frazell EL, Lewis JS: Cancer of the nasal cavity and accessory sinuses - A report of the management of 416 patients-. Cancer $16: 1293-1301$, 1963.

3 ) Boone ML, Harle TS, Higholt HW, et al : Malignant disease of the paranasal sinuses and nasal cavity. Importance of precise localization of extent of disease. Am J Roentgenol 102 : 627-636, 1968.

4) Hawkins RB, Wynstra JH, Pilepich MV, et al : Carcinoma of the nasal cavity-Results of primary and adjubant radiotherapy-. Int $\mathrm{J}$ Radiat Oncol Biol Phys 15 : 1129-1133, 1988.

5 ) Moran CA, Wenig BM, Mullick FG : Primary adenocarcinoma of the nasal cavity and paranasal sinuses. Ear Nose Throat J 70: 821-828, 1991.

6 ) Euteneuer S, Sudhoff H, Bernal-Sprekelsen M, et al: Malignomas of the nasal cavity and paranasal sinuses: Clinical characteristics, Therapy and Prognosis of different tumor types. Laryngo-Rhino-Otol 83 : 33-39, 2004.

7 ）田村光司, 千々和圭一, 森 一功, 他：鼻腔悪性腫 瘍の臨床的検討.耳鼻 $45 ： 357-363,1999$.

8 ）小川晃弘：鼻・副鼻腔癌の病理組織学的検討 (1) 腺 癌. 日耳鼻 $92: 317-333,1989$.

9 ）近藤 隆, 河辺義孝：鼻腔癌症例の検討. 耳鼻臨床 $76:$ 1405-1412, 1983.

10) Blacklock JB, Weber RS, Lee $Y$, et al : Transcranial resection of tumor of the paranasal sinus and nasal cavity. Am J Clin Oncol 12: 387-392, 1989.

11）佐藤公則，平野 実，坂口伸治，他：頭頸部悪性腫 瘍に対する前頭蓋底手術。耳鼻臨床 補80：67-72, 1995.

12) Satoshi F, Noboru S, Shin-etsu K, et al: Surgical results of skull base surgery for the treatment of head and neck malignancies involving skull base: multi-institutional studies on 143 cases in Japan. Auris Nasus Larynx 28 : 71-75, 2001.

13) Ian G, Snehal GP, Bhuvanesh S, et al: Complications of cranifacial resection for malignant tumors of the skull base: Report of an international collaborative study. Head Neck 27 : 445-451, 2005.

14）坂本菊男，清川兼輔，宮嶋義巳，他：前頭蓋底に浸 潤した鼻・副鼻腔悪性腫瘍. 頭頸部外科：投稿中.

15）坂本菊男，宮嶋義巳，中島 格，他：鼻副鼻腔癌の 選択的動注化学療法一適応と限界一. 頭頸部癌 $31: 408-411,2005$.

16）久 育男，安田範夫，只木信尚，他：頭頸部腺様囊 胞癌の臨床. 日耳鼻 $95 ： 346-351 ， 1992$.

17) McNicoll W, Hopkin N, Dalley VM, et al : Cancer of the paranasal sinuses and nasal cavities-Part 2 results of treatment-. J Laryngol Otol 98: 707718, 1984.

18) Hu WH, Xie FY, Chen DZ, et al: Prognosis and treatment for 98 patients with carcinoma of nasal cavity. Ai Zheng 23 : 1542-1545, 2004.

19) Szanto PA, Luna MA, Tortoledo ME, et al : Histologic grading of adenoid cystic carcinoma of the salivary glands. Cancer 54: 1062-1069, 1984.

20）梅野博仁，宮嶋義巳，森一功，他：頭頸部腺様囊 胞癌54例の臨床統計。日耳鼻 $100: 1442-1449$, 1997.

21) Orvidas LJ, Lewis JE, Weaver AL, et al : Adenocarcinoma of the nose and paranasal sinuses: A retro spective study of diagnosis, histologic characteristics, and outcomes in 24 patients. Head Neck 27 370-375, 2005 .

22）坂本菊男，千々和秀記，宮嶋義巳，他：耳下腺悪性 腫瘍74例の臨床的検討. 日耳鼻 109：103-111, 2006.

23) Abecasis J, Viana G, Pissarra C, et al: Adenocarcinoma of the nasal cavity and paranasal sinuses: a clinicopathological and immunohistochemical study of 14 cases. Histopathology 45 : 254-259, 2004.

24）坂本菊男，伊豆丸慎介，栗田知幸，他：粘表皮癌の 臨床病理学的検討. 日耳鼻 $108: 142-149,2005$.

25) Pires FR, de Almeida OP, de Araujo VC, et al : Prognostic factors in head and neck mucoepidermoid carcinoma. Arch Otolaryngol Head Neck Surg. 130 : 174-180, 2004.

26) Baugh RF, Wolf GT and McClatchey KD : Small 
cell carcinoma of the head and neck. Head Neck Surg 8 : 343-354, 1986.

27) Kane WJ, McCaffrey TV, Olsen KD, et al: Primary parotid malignancies ; a clinical and pathologic review. Arch Otolaryngol Head Neck Surg 117 : 307-315, 1991.

28) Hakuba $N$, Hyodo $M$, Yokoi $T$, et al: Irinotecan (CPT-11) combined with cisplatin for small cell carcinoma of the nasal cavity. Auris Nasus Larynx
$32:$ 776-780, 2005.

（2005年10月13日受稿， 2006年 2 月 6 日受理） 別刷請求先：坂本 菊男

干830-0011 福岡県久留米市旭町67番地 久留米大学医学部耳鼻咽喉科 - 頭頸部外科学講座

Tel : 0942-31-7575 Fax : 0942-37-1200

e-mail : skikuo@med.kurume-u.ac.jp 